\title{
A Proposal for Evaluation in Schools: Multifaceted Evaluation for the Facilitation of Learning and Instruction
}

\author{
Rivka Glaubman*, Hananyah Glaubman \\ Bar-Ilan University, Ramat-Gan, Israel.
}

\begin{abstract}
How to cite this paper: Rivka Glaubman, Hananyah Glaubman. (2021). A Proposal for Evaluation in Schools: Multifaceted Evaluation for the Facilitation of Learning and Instruction. The Educational Review, USA, 5(5), 146-154.

DOI: 10.26855/er.2021.05.005
\end{abstract}

Received: April 6, 2021

Accepted: April 30, 2021

Published: May 27, 2021

Corresponding author: Rivka Glaubman, Bar-Ilan University, Ramat-Gan, Israel.

Email: glaubmr@bezeqint.net

\begin{abstract}
Evaluation should correspond with the method of teaching. However, in practice, state authorities almost solely drive towards an achievements' evaluation. We disapprove of the current state of evaluation policy and promote the use of alternative assessment methods. Thus, we suggest: (1) Assessment should be designed to suit a continuous sequence of teaching-learning-and evaluation, where assessment plays the role of feedback; (2) Assessment must be varied in alternative methods, to correspond with divergent teaching objectives and meet various learners and learning situations; (3) For learning to occur, students should be active in all domains, learning as well as evaluation. They should be involved in active learning, students' mutual teaching, and self-evaluation. In the present work, we propose a model of alternative methods in classroom assessment. The model presents three levels: Level 1-A traditional normative approach of direct teaching and directive assessment, aimed at socialization and acquiring common knowledge and basic skills. Assessment of these pre-set goals requires at a lower stage objective summative testing, and at a more advanced stage-formative or value-added assessment. Level 2-An interpretive empowering approach, which aims at developing learner's self-directed-learning through independent and cooperative study. Evaluation is conducted in alternative ways, including teacher's facilitative feedback, and pupil's self- and mutual-assessment. Level 3-A personal approach, which seeks to develop inner self-growth powers of learning and to accommodate each person's unique aims and interests. At this level, self-evaluation of one's own goals is encouraged, to facilitate growth and foster autonomy.
\end{abstract}

\section{Keywords}

Multifaceted Evaluation, Self-Assessment, Alternative Methods, Summative and Formative Assessments

\section{Introduction}

In the last three decades, both the theory of education, as well as the practice of education, went through major changes. Regarding these changes, the issue of evaluation became salient. In this context, we propose a model of alternative methods in classroom assessment. Teachers' aims and assumptions lead directly to the specific methods they use 
for teaching- learning- and evaluation of pupils (Chen, 1998). The aims are based upon their basic perceptions of schooling regarding culture (including basic skills and curriculum mastery), society (social studies and interpersonal relationships), and individuals (competencies and intrapersonal development). Becher (1972), del Pozo Garcia, (2019), DeLuca et al., (2020), Joyce and Weil (1985), McDonald (1968), and others claim that schooling should combine all three groups of aims. Theorists and researchers highly recommend the combining of all three groups of aims. However, in practice, state authorities drive mainly towards achievements' evaluation stemming from the first group of standard-based instruction (Tomlinson, 2000). In contrast, academic researchers act as proponents of the second (cooperative leaning) (Slavin, 1988), or the third (self-regulation) goals (Ryan \& Deci, 2000; Porter, 1993; Zimmerman, 1996). The emphases changed gradually in time, but standard-based assessment still prevails in official policy (e.g., OFSTED, 1999).

\section{Proposal-Materials and Methods}

Following the above-mentioned understandings, we present the main beliefs currently prevailing in the field of education: a). The traditional conservative approach and method claims that learning is the outcome of imitation. The method of teaching is based upon this belief as follows: The teacher presents to the pupil a model, the pupil imitates the teacher, and that is how s/he learns (How to read, to write, to cut to size, to read a map, etc.). This way of teaching is based on the conviction that people on their own lack the knowledge of how to do things, but they do possess abilities, skills and motivation and if they are shown how, they will try, preform and practice and so they will learn. That is also the logic of apprenticeship in which the apprentice acquires a profession by imitating his/her master and practicing. The main flaw in this method is that the pupil does not acquire a flexible mastery even in the narrow field in which s/he studied. b). A bit more advanced method is the didactic method. In this method the teacher presents the students with facts, principles and laws, and the students watch, listen, learn, remember, acquire knowledge and apply it. The logic that underlies this approach is as follows: People are born with no knowledge at all—“Tabula Rasa”, nevertheless they possess a range of abilities: verbal abilities, space abilities, numeral abilities, interpersonal abilities, etc. These abilities continue to develop a long time. The world contains a vast amount of important knowledge, and people need a professional person who can teach and explain it to them, they also expect that someone will provide them with this knowledge so that they will learn. Thus, the teacher must explicitly define what s/he wants to teach, to prepare a teaching plan and execute it, and to decide how s/he is going to evaluate what in fact did the pupils acquire. The problem with this method is that although the pupil can acquire a large amount of knowledge, s/he does not learn how to learn and apply his/her learning abilities to new situations. S/he also does not get the opportunity to establish for him/herself his/her own self meaning of what s/he has learned. c). A third approach to learning and methods of teaching maintains that learning is achieved by mutual interaction. Applying this method demands the teacher's understanding of the pupil's viewpoint, and following this understanding to provide him/her with appropriate experiences and aid him/her in understanding better his/her experiences by encouraging him/her to have interactions and negotiations with others that have different understandings than his/her own. The basis of this method is the conviction that everyone has logic and can think for him/herself and can also examine critically his/her own thinking and correct it by reflecting upon it. People, including young children, have their own theories about the world, and about the proper way to learn. Their minds contain beliefs and opinions and they change and develop them by interacting with others. Interactions, discussions and negotiations with the opinions and viewpoints of others serve as a way to learn. When the student arrives at the classroom, s/he possesses already his/her own understanding of the world, which s/he established based on his/her previous experiences and interactions with others, while aiming to understand these experiences. The problem is that when applying this method, where the pupil is the center, his/her knowledge is built on local information available to him/her and ability to substantiate his/her views. This method hardly allows the usage of accumulated scientific and cultural knowledge. What is missing is the scientific and philosophical body of thought and knowledge accumulated along the ages. d). The fourth method is conceiving learning as a process of dialog with the existing knowledge. It is applied in the following way: Both teacher and pupil take an active part in the process. The students experience learning in social and environmental contexts. The teacher helps the students to distinguish between their personal knowledge and common knowledge, and to understand how it became common. To realize that one must apply logical mental processes to form hypothesis, to examine it and to justify his/her conclusions based on reliable proof. This approach is based on the fact that along the time a lot of information was accumulated in the different cultures, as well as improvements in research methods. Even children can distinguish between what is known to me and what is a wider common knowledge that is accepted by the broad society. Thus, in this kind of learning the dialog is not only with contemporary others but with past generations as well. The limitation of this method is that while it serves well to develop a scientific approach and investigative learning, it is not so suitable for subject matters that are not scientific (such as literature, art, bible etc.), and to achieve other ob- 
jectives such as acquiring skills and experiential learning.

\section{Discussion}

When we examine the existing state of evaluation in the light of the above analysis, we identify four problems: A. The messages as to what is "really important" in education come downward from the authorities to the school management, from the management to the teachers and from the teachers to the pupils. This is done by the means of evaluation (Dochy, 2000). Therefore, there is the danger that instead of educational policy and ideology, the aims of the educational routine will be determined by the evaluation. That is what had happened at the 80s in the USA when the new tests that were introduced at the time, determined what was learned in the classroom. The same occurred in Israel too. Schools directed their teaching according to the national and regional tests that were introduced at the time. The results were that instead of tests serving the educational goals, the educational goals, curriculum and teaching, served the tests. B. At the end of the 20th century and during the 21th century, many changes occurred in the conception of learning and accordingly also of evaluation (DeLuca et al., 2020; del Pozo Garcia, 2020; Mayer, 2001; Perkins, 1992; Pratt, 2020; Yan, 2020), but in reality most of external evaluation (International, national and regional) consisted of tests concentrating on examining knowledge. As a result, curriculum and teaching were directed too to concentrate on acquiring knowledge. C. Examinations test mainly memory of data. Research showed that the nature of the activity by which the data were acquired, determines to a large extent the long-term memory. Only $5 \%$ of data acquired by listening to a lecture is remembered for a long time. $10 \%$ of read material is remembered in long time memory, $20 \%$ of material acquired by observing audio visual presentation, $30 \%$ material is gained by demonstration, $50 \%$ of what was discussed in a discussion group, $75 \%$ learned by acting, and when one teaches others or makes a practical use of what s/he has learned, the material is recorded in a long time memory. It is clearly demonstrated that the more active and initiative the student is at the learning process, s/he will remember what s/he has learned for a longer time (Sousa, 2001). This important aspect is not measured by the tests. D. Most of the tests, mainly the standard national tests, are annual tests and in many cases are not specific to the learned material (Marzano, 2003). When the pupils are tested on their mastery of the knowledge and skills they were taught, the order of the process is as follows: a). Defining the goals of learning. b). Planning of the teaching to achieve the goals c). Presenting the students with explanations, stimuli, and activities that will aid the learning. d). Evaluation in order to appreciate to what extent were the goals achieved. e). Reflecting and analyzing the results in order to plan the next steps. This order seems appropriate in the case when transfer of knowledge and training of known skills are concerned. But the order is completely different when active reconstructing meaning by the student is concerned, as Conner, Perkins and Unger defined learning (Conner, 1999; Perkins \& Unger, 1999) or as Dochy phrased it: "Learning means active reconstruction of knowledge and skill on the basis of existing knowledge" (Dochy, 2001, p. 15). In this case evaluation comes as the first step, and the order will be as follows: a. Collecting data to enable evaluation as of what is the environment perception and the existing knowledge of the student. b. Reflecting and analyzing the data in order to plan the selection learning stimuli suitable for achieving the learning goals, c. Presenting the student with stimuli and activities which s/he can connect with his/her existing knowledge, and construct his/her understanding of the new material, while negotiating with his/her learning colleagues. d. Observing the students at work and collecting data on the way of their studying.

Thus, we may see why the present tests are not suitable for education as it is currently perceived. As the educational approach emphasizes the goal of helping the student to develop his/her own meaning of the studied material, evaluation of teaching and of learning cannot be done by tests which examine mastery of acquired knowledge. Nevertheless, it is clear that among the aims of education the goal to teach basic skills is an important one, and that has to be evaluated in order to be able to intervene with necessary aids. The approach that consider learning as a process in which the student construct his/her own knowledge, demands that the planning of the teaching-learning-evaluation cycle will include a variety of aspects: Cognitive (knowledge, comprehension, meaning), Physical environmental (stimuli, accessibility, acceptance, comfort), Emotional (confidence, support), and Social (communication, learning from others, social interaction). This kind of educational approach creates a challenge for a suitable evaluation system. We offer as a way of dealing with this problem the Multifaceted Evaluation Model. The Multifaceted Evaluation Model which is proposed here disagrees with opposing the displacement of one evaluation method and replacing it by another.

The approach that we suggest here disagrees with opposing the displacement of one evaluation method and replacing it by another. On the contrary, the approach we present maintains a comprehensive, inclusive approach to evaluation. We intend to point out why it is wrong to apply just the new authentic methods of evaluation, as some of the researchers such as Darling-Hammond and Newmann suggest (Darling-Hammond et al., 1995; Newmann, 1997). They suggest replacing the existing old methods of tests given by the teacher or the authorities and introducing in their place the new authentic methods. Unlike them, we believe that even in our times when "The meaning of learning is active construc- 
tion of knowledge and skills on the basis of existing knowledge” (Dochy, 2001, p. 15), there is still a place for teaching and evaluation that are initiated and directed by the teacher. There are various types of learning, and the role of evaluation is to gather information in flexible different methods according to the type of learning that is evaluated (Buelin et al., 2019; Greer \& Mark, 2016; del Pozo Garcia, 2020; DeLuca et al., 2020; Lee et al., 2020).

The learning environment ought to be typified by balancing the various types of learning, e.g., the teaching of basic knowledge and simple skills that requires testing, or discovery and research learning that requires open and alternative methods of evaluation. The school ought to encompass and give answers simultaneously to a whole set of needs that are expressed in the unique as well as different goals of educational approaches, those that are aiming at the needs of society beyond the needs of the individual, and those that are focused on the development and growth of the individual as a self-defined and autonomous person who expresses his/her unique personality, in disregard of his/her social belonging (Becher, 1972; Buelin et al., 2019; McDonald, 1968; Porter, 1993). In accordance, methods of evaluation should be fitted to examine to what extent the different goals are achieved by the learning process. Therefore, we join Buelin et al. (2019) in the claim that it is not recommended to replace the old methods by the new ones, but rather to accept them as complimentary. Each method serves a different goal and will be applied according to the specific type of learning it intends to serve.

As we already claimed, the approaches to learning should be divided into four: The traditional conservative approach; a bit more advanced method which we called the didactic method; a third approach that regards learning as achieved by mutual interaction; and a fourth method which is perceiving learning as a process of a dialog with existing knowledge. The first two approaches expect the learner to show basic knowledge and mastery of basic skills (Buelin et al., 2019; Schoonmaker, 2001), as well as understanding and mastering skills of an enlightened citizenship. These are expressed by obtaining views, knowledge, skills and habits, which are necessary for citizens in order to take part in all range of responsibilities of a citizen in a democratic society (Kamradt \& Kamradt, 1999; Schoonmaker, 2001). Accordingly, evaluation methods suitable for this type of learning would be objective tests which will test to what extent these objectives were achieved by all the learners. While recognizing the suitability of these methods to test this type of learning we should be aware of the following points of criticism:

1. The educational experience around the world showed that it is impossible to get all the students to equally reach the goals of learning. Not even if we try to define exactly and phrase precisely and clearly the behavior that characterizes the behavior of one who achieved the goal (Swenson, 1950; Mayer, 2001; Pratt, 2020).

2. Many of the educational objectives cannot be accurately measured. For example, complicated learning, learning of high intellectual material, originality and creativity and such (Kennedy, 1999), and learning of subject matters involving artistic aspect or moral and educational aspects, the results of which will appear long after they were learned, sometimes after the pupil already left school (Eisner, 1988).

3. When tests are applied as a principal way of examining knowledge, the result is that schools concentrate on unimportant issues and neglect the significant ones.

4. The tests test only what can be measured (White,1999), which is the ability of the pupil to show what he knows, this leads a great group of pupils to believe that they are inferior or stupid, even though they are not (English \& Kaufman, 1975; Hagiwara et al., 2020).

5. An attempt to overcome the problems mentioned in paragraph 4 was made by designing tests that consider the individual's range of ability to achieve. Nevertheless, the distinction among individuals was revealed only in the pace of study and in the results, and not in checking the suitability of the goals for them (Al Seghayer, 2020; Bloom, 1976; Hagiwara, 2020; Yan, 2020).

6. Tests that lead to concentration on knowledge rather than on the development of thinking, are damaging for proper education (Yan, 2020).

7. Concentrating just on the acquiring of knowledge creates a school atmosphere, which makes the teacher feel a load of pressure s/he cannot bear (Perkins, 1992).

To sum up, there is a need for learning basic knowledge and acquiring basic skills, and for this type of learning objective tests seem proper to be the evaluation method. Nevertheless, those should not be the sole way of evaluation. A wider range of methods is needed for other important goals of education. And as to the objective tests, it is preferable that they should be prepared by the teacher according to the specific material s/he taught, in a way that they will measure the additional knowledge the pupil acquired in comparison to his/her previous knowledge and will show the amount of his/her progress (Marzano, 2003).

The other two approaches we referred to were as follows: An approach that maintains that learning is achieved by 
mutual interaction, and an approach which is perceiving learning as a process of a dialog with existing knowledge. Both approaches concentrate on the meaning of the learned knowledge that is built by the students themselves. In the case of the third approach, the teacher is not involved directly in the building of that meaning, s/he only prepares the materials that lead to the acquisition of the knowledge, while in the fourth approach the teacher takes part in order to connect the learner's knowledge with the existing one. The learning within the framework of these two approaches encompasses a wide range of skills and knowledge and the performance of research and learning tasks involved in this sort of learning requires processing on a high cognitive level. Evaluation methods should change in accordance with the changes in the ways of teaching. This is so especially when high level learning tasks need to be evaluated (Greer \& Mark, 2016; Mayer, 2001; Lee et al., 2020). The appropriate evaluating methods for these kinds to learning are alternative ways of evaluation, mainly authentic ones in which the pupil is performing learning tasks that are connected to real life situations in ways of problem solving. For this purpose, s/he must deal with and work on a variety of materials that are made available in his/her learning environment. In this case the evaluation method should be open and alternative and the pupil should take an active part in a common venture of teacher-pupil, in which the teacher's part is to organize and make them available (Hunter, 1982; Mayer, 2001; Sousa, 2001; Wolfe, 2001). The underlying assumption of this approach is that the learner advances in his/her learning pace as s/he recognizes the meaning and lessons of his/her experiences in cycles of feedbacks and mutual and self-evaluations (Piaget, 1973; Berk, 1994; Bruner, 1996; Mayer, 2001; Wood, 1998; Yan, 2020).

We follow Buelin et al. (2019), Davis (1999), Humbleton (1996), Terwilliger (1997) and others, which criticize the current use of evaluation policy and performance in schools and assert for the use of alternative methods in classroom assessment. Thus, we claim:

1. For a continuous sequence of teaching-learning-and evaluation (Assessment Reform Group, 1999; Buelin et al., 2019), where the teacher observes the student's attempts at learning, and conducts instruction as a feedback interacting with that which was observed. The teacher seeks first to comprehend the student's inner understanding, thinking processes and motivations, in order to interact with the needs exposed in this process. This leads to the conclusion that assessment should be focused upon the students' attempts at implementing prior knowledge and skills they have acquired in new leaning situations. Therefore, evaluation plays an integrative and essential part in teaching that facilitates learning.

2. As learning types are multi-faceted and divergent, conducted in varied situations, and unique for each student, so must assessment be varied in alternative methods, to meet various learners, learning situations, and various learner’s authentic goals (Marzano, 2000; Buelin et al., 2019; Lee et al., 2020).

3. For learning to occur, learners should be active in all domains, in self- and mutual-teaching, learning as well as evaluation (Al Seghayer, 2020; Fetterman, 1996).

The Multifaceted Evaluation model was designed to answer these demands.

The idea of alternative methods for evaluation is not new. However, we add to it the aspect of a complementary, holistic approach, starting with mapping of the various multi types of leaning tasks in schools, and in accordance, suggest various suitable multifaceted methods of evaluation. We tend to ways, which facilitate learners' capability in varied ways of learning and multifaceted self-evaluation.

The multifaceted evaluation model we suggest refers to three levels:

First level - the traditional normative approach, of direct teaching and directive-assessment, which tends to generations' old heritage transfer of culture, common knowledge and basic skills. Assessment of these, at a lower stage, requires methods of objective summative testing. In a relatively advanced stage, it uses formative (Torrance \& Pryor, 1998), or value-added assessment (DFE, 1995; Saunders, 1999), which guides the learners in the acquisition of pre-set goals (Buelin et al., 2020).

Second level—an empowering interpretive approach (Blase \& Anderson, 1995; Fetterman, Kaftarian \& Wandersman, 1996), which aims to develop self-directed learning in ways of independent and cooperative study and research, and suitable alternative methods of evaluation. It offers ways of performance- or authentic-assessment (Darling-Hammond, Ancess \& Falk, 1995; Hambleton, 1996), and encourages ways of self- and mutual-assessment (Asp, 2000; Earl \& LeMahieu, 1997; Lee et al., 2020).

Third level—a personal approach, which seeks to develop inner self-growth powers of learning, to accommodate for each person's unique aims and interests (Williams \& Sternberg, 1993). At this level self-evaluation of self-goals are encouraged (Hansen, 1998; Yan, 2020), so that a person may contribute to the facilitation of his or her own autonomy. At the same time, autonomous learners are constantly encouraged to cooperate with their peers and contribute to and enrich their close and wider society using the unique developed powers they acquired for this end (McDonald, 1968). 
Thus, unique, appropriate, teacher and pupil activities for teaching, learning and evaluation characterize each level, as presented in Figure 1 below.

\begin{tabular}{|c|c|c|c|c|}
\hline Levels $\rightarrow$ & \multicolumn{2}{|c|}{ Level 1 - } & Level 2 - & Level 3 - \\
\hline Activities $\downarrow$ & Normative & Formative & Interpretive & Personal \\
\hline Teaching & Directing & Guiding & Empowering & Growing \\
\hline \multirow[b]{2}{*}{ Learning } & \multicolumn{2}{|c|}{$\begin{array}{l}\text { Acquiring basic knowledge \& skills in } \\
\text { curriculum disciplines, following cultural } \\
\text { socialization }\end{array}$} & \multirow{2}{*}{$\begin{array}{l}\text { Self-direction, } \\
\text { Planning and implementing } \\
\text { projects, using criteria for } \\
\text { self-evaluation }\end{array}$} & \multirow{2}{*}{$\begin{array}{c}\text { Experimenting, } \\
\text { self-coping, taking own } \\
\text { decisions, } \\
\text { self-awareness, using } \\
\text { own criteria for } \\
\text { self-evaluation }\end{array}$} \\
\hline & $\begin{array}{l}\text { following direc- } \\
\text { tions, practicing }\end{array}$ & $\begin{array}{c}\text { Understanding } \\
\text { self-progress, con- } \\
\text { ducting small scale } \\
\text { teacher-directed stu- } \\
\text { dies }\end{array}$ & & \\
\hline Evaluation & $\begin{array}{l}\text { Summative } \\
\text { testing \& grad- } \\
\text { ing for place- } \\
\text { ment }\end{array}$ & $\begin{array}{l}\text { Formative testing \& } \\
\text { value-added assess- } \\
\text { ment, for further di- } \\
\text { rection of teaching }\end{array}$ & $\begin{array}{l}\text { Diagnosing through alterna- } \\
\text { tive methods, giving correc- } \\
\text { tive feedback for further } \\
\text { learning tasks }\end{array}$ & $\begin{array}{l}\text { Identifying needs, assist- } \\
\text { ing self-awareness, iden- } \\
\text { tifying and removing } \\
\text { learning blocks }\end{array}$ \\
\hline
\end{tabular}

Figure 1. The multifaceted model of evaluation

Therefore, both teachers and pupils need to develop and master different evaluation competencies for each type. The teacher ought to serve as diagnostician for assessment in all types of learning, but also to specialize in specific evaluation methods to accommodate for each level. Develop objective-normative and criterion-based competencies for the directive and guidance assessment at the $1^{\text {st }}$ level; use interpretive-reflective competencies for the empowering assessment at the $2^{\text {nd }}$ level; and master personal-open-experiential competencies for the growth evaluation at the $3^{\text {rd }}$ level. In parallel, the pupil needs to develop his/her competencies. Be ready to accept positive as well as critical feedback, to change and correct in reaction, at the $1^{\text {st }}$ level; to interpret information and use alternative methods for self-assessment using appropriate to criteria, at the $2^{\text {nd }}$ level; and to make critical use of information, to self-develop of- and adapt- appropriate criteria for evaluation, and use self- and mutual-feedback to evaluate achievement of own authentic purposes, at the $3^{\text {rd }}$ level.

Our unique approach maintains that the various versions of learning-teaching- and evaluation are not replacing each other. Rather, they are all simultaneously valid and relevant in school learning and are alternatively used according to the various specific goals and types of learning. In accordance, so is the learning environment, within which teaching and learning takes place. Albeit, the proportion they take are constantly changing, as the student becomes more proficient in the advanced levels of learning and evaluation. Mastery of basic skills, essential cultural values and declarative knowledge acquisition entail learning from direct and guided teaching (Shuell, 1996), and thus entail also level-1 assessment. Procedural knowledge of implementing in new situations, acquired research skills in social, multidisciplinary and interdisciplinary areas of learning, and developing of high order cognitive change, require empowering teacher guidance with a growing share of the learner, in a rich and varied environment, and interpretive alternative level-2 assessment methods. Developing of self-decision taking, self-construction of knowledge at an interdisciplinary and transdisciplinary level (Petrie, 1992), using metacognitive self-regulated learning, with growing self-awareness to own processes in a diverse school and life environments, mostly student's initiated, entail the usage of level-3 evaluation. Evaluation, like all learner actions at this level, is mostly initiated by the reflective learner, and remotely accompanied by the observing teacher.

\section{Conclusions}

When teaching-learning- and evaluation are combined to define the educational policy as a multifaceted program that includes the above-mentioned types of teaching and evaluation, it makes possible the gradual transforming of school-and teacher-initiated- way of teaching to a learner-initiated-learning. The student begins in following directions, becomes a partner who chooses what to learn, moves on to become an independent empowered learner, and grows to become initiator and developer of own learning. In consequence, planning, performing and evaluating of learning moves gradually from the teacher to the student. However, the proportion of the different methods of evaluation used, depends on the proportion of the various learning types used in classroom learning. As one of the major ultimate aims of schooling is the achievement of a $3^{\text {rd }}$ level type of learner, classroom teaching should follow the above program, and 
hence will lead the advancing student to gradually take a growing share in his/her own learning and evaluation. A learner, who learns to set his/her own goals, learns also how to achieve them, and how to critically evaluate the process and the quality of the results in reference to own progress and to the relevance and contribution of the achievements to his/her social and ecological environment. On the other hand, a teacher who sets the $3^{\text {rd }}$ level goals for the facilitation of his/her students, becomes more sensitive to students' needs on their progress toward this aim, thus, this approach to education should be considered as preferable and adopted for application in the classroom.

\section{References}

Al Seghayer, K. (2020). Investigating the adequacy of EFL learners’ L2 digital literacy skills, consistency of self-assessed competence, and actual performance. International Journal of Computer-Assisted Language Learning and Teaching, 10(2), 1-22.

Anderson, L. A. and Sosniak, J. (Eds.). Bloom's taxonomy: A forty-year retrospective (pp. 82-102). Chicago, IL: Ninety-Third Yearbook of the NSSE, Part II. The University of Chicago Press.

Asp, E. (2000). Assessment in education: Where have we been? Where are we going? In R. S. Brandt (Ed.), Education in a new era (pp. 123-157). Alexandria, VA: 2000 ASCD Year Book.

Assessment Reform Group. (1999). Assessment for learning: Beyond the black box. Cambridge: University of Cambridge School of Education.

Becher, R. A. (1972). Three styles of curriculum development. In S. Maclure (Ed.), Styles of curriculum development. Paris: OECD, Centre for Educational Research and Development Innovation (CERI).

Berk, L. E. (1994, 3rd Edn.). Child development. Boston: Allyn and Bacon.

Blase, J. and Anderson, G. L. (1995). The micropolitics of educational leadership: From control to empowerment. London \& NY: Cassell.

Bloom, B. S. (1976). Human characteristics and school learning. NY: McGraw Hill.

Bruner, J. (1996). The culture of education. Cambridge: Harvard University Press.

Buelin, J., Ernst, J, V., Clark, A. C., Kelly, D. P., and DeLuca, V. W. (2019). Formative evaluation techniques. Technology and Engineering Teacher, 78(5), 21-23.

Chen, H. (1998). Theory-driven evaluation. In A. J. Reynolds \& H. J. Walberg (Eds.), Advances in educational productivity: Evaluation research for educational productivity. Vol. 7 (pp. 15-34). London: JAI Press Inc.

Conner, C. (1999). Assessment in the primary school: A review of current research. In C. Conner (Ed.), Assessment in action in the primary school (pp. 9-32). London: Falmer Press. Primary Directions Series.

Darling-Hammond, L., Ancess, J., and Falk, B. (1995). Authentic assessment in action. NY: Columbia University Press.

Davis, A. (1999). Impact no. 1. Educational assessment: A critique of current policy. GB: The Philosophy Education Society of GB. (J. White, Ed.).

del Pozo García, A. (2019). Raising Awareness on Assessment Criteria through Peer-Assessment and Self-Reflection in the Spanish Oral Class. Research-publishing.net. Five Years of ELEUK Conferences: A Selection of Short Papers from 2019, see ED606532.

DeLuca, C., Schneider, C., Coombs, A., Pozas, M., and Rasooli, A. (2020). A cross-cultural comparison of German and Canadian student teachers' assessment competence. Assessment in Education: Principles, Policy \& Practice, 27(1), 26-45.

DFE (Department for Education). (1995). Value added in education. London: The Stationary Office.

Dochy, F. (2001). A new assessment era: Different needs, new challenges. Research Dialogue in Learning and Instruction, 2, 11-20.

Earl, L. M. and LeMahieu, P. G. (1997). Rethinking assessment and accountability. In A. Hargreaves (Ed.), Rethinking educational change with heart and mind (pp. 149-168). Alexandria, VA: 1997 ASCD Year Book.

Eisner, E. (1988). The art of educational evaluation: A personal view. London: The Falmer Press.

English, F.W. and Kaufman, R.A. (1975). Needs assessment: A focus for curriculum development. Washington, DC: Association for Supervision and Curriculum Development.

Fetterman, D. M. (1996). Empowerment evaluation: An introduction to theory and practice. In Fetterman, D. M., Kaftarian, S. J., \& Wandersman, A. (Eds.), Empowerment evaluation: Knowledge and tools for self-assessment and accountability (pp. 3-46). Thousand Oaks: Sage Pub.

Greer, J. and Mark, M. (2016). Evaluation Methods for Intelligent Tutoring Systems Revisited. International Journal of Artificial Intelligence in Education, 26(1), 387-392.

Hagiwara, M., Shogren, K. A., Lane, K. L., Raley, S. K., and Smith, S. A. (2020). Development of the self-determined learning mod- 
el of instruction coaching model: Implications for research and practice. Education and Training in Autism and Developmental Disabilities, 55(1), 17-27.

Hambleton, R. K. (1996). Advances in assessment models, methods, and practices. In D. C. Berliner \& R. C. Calfee (Eds.), Handbook of educational psychology (pp. 899-925). NY: Macmillan.

Hansen, J. (1998). When learners evaluate. Portsmouth, NH: Heinemann.

Hunter, M (1982). Mastery teaching. El Segundo, CA: T.I.P. Pub.

Joyce, B. R. and Weil, M. (1985). Models of teaching. NJ: Prentice-Hall.

Kamradt, T. F. and Kamradt, E. J. (1999). Structured design for attitudinal instruction. In C. M. Reigeluth (Ed.), Instructional-design theories and models, Vol II: A new paradigm of instructional theory (pp. 563-590). Mahwah NJ: Lawrence Erlbaum Ass. Pub.

Kennedy, M. M. (1999). Approximations to indicators of student outcomes. Educational Evaluation and Policy Analysis, 21(4), 345-363.

Lee, H., Chung, H. Q., Zhang, Y., Abedi, J., and Warschauer, M. (2020). The effectiveness and features of formative assessment in US K-12 education: A systematic review. Applied Measurement in Education, 33(2), 124-140.

Marzano, R. J. (2000). Transforming classroom grading. Alexandria, VA: ASCD.

Marzano, R. J. (2003). What works in schools: Translating research into action. Alexandria, VA: ASCD.

Mayer, R. E. (2001). Changing conceptions of learning: A century of progression in the scientific study of education. In L. Corno (Ed.), Education across a century: The centennial volume (pp. 34-75). Chicago, IL: One Hundredth Yearbook of the NSSE, Part I, the University of Chicago Press.

McDonald, J. (1968). Values bases and issues for curriculum. In D. Hearn, J. Burding \& L. Katz (Eds.), Current research and current perspectives in open education. Washington, D.C.: Association of Elementary Kindergarten-Nursery Education.

Newmann, F. M. (1997). Authentic assessment in social studies: Standards and examples. In G. D. Phye (Ed.), Handbook of classroom assessment: Learning, adjustment, and achievement (pp. 359-380). San-Diego, CA: Academic Press.

OFSTED (Office for Standards in Education). (1999). Inspecting schools: The Framework. London: The Stationary Office.

Perkins, D. (1992). Smart schools: From training memories to educating minds. NY: The Free Press, A Division of Macmillan, Inc.

Perkins, D. and Unger, C. (1999). Teaching and learning for understanding. In C. M. Reigeluth (Ed.), Instructional-design theories and models, Vol II: A new paradigm of instructional theory (pp. 91-113). Mahwah NJ: Lawrence Erlbaum Ass. Pub.

Petrie, H. G. (1992). Interdisciplinary education: Are we faced with insurmountable opportunities? G. Grant (Ed.), Review of Research in Education, 18, 299-333.

Piaget, J. (1973). To Understand Is to Invent - The Future of Education. NY: C. Grossman.

Porter, A. C. (1993). School delivery standards. Educational Researcher, 22 (5), 24-30.

Pratt, S. M. (2020). A mixed methods approach to exploring the relationship between beginning readers' dialog about their thinking and ability to self-correct oral reading. Reading Psychology, 41(1), 1-43.

Ryan, R. M. and Deci, E. L. (2000). Self-determination theory and the facilitation of intrinsic motivation, social development, and well-being. American Psychologist, 55(1), 68-78.

Saunders, L. (1999). 'Value added' measurement of school effectiveness: A critical review. Slough: NFER.

Schoonmaker, F. (2001). Curriculum making, models, practices and issues: A knowledge fetish? In L. Corno (Ed.), Education across a century: The centennial volume (pp. 1-33). Chicago, IL: One Hundredth Yearbook of the NSSE, Part I, the University of Chicago Press.

Shuell, T. J. (1996). Teaching and learning in a classroom context. In D. C. Berliner \& R. C. C. Calfee (Eds.), Handbook of educational psychology (pp. 726-764). NY: Macmillan.

Slavin, R. E. (1988). Synthesis of research on grouping in elementary and secondary schools. Educational Leadership, 46(1), 67-77.

Sousa, D. A. (2001). How the Brain Learns (2nd Edn.). Thousand Oaks, CA: Corwin Press, Inc., A Sage Pub. Co.

Terwilliger, J. S. (1997). Portfolios and Classroom Assessment: Some Claims and Questions. Minnesota: Repots-Evaluative, The ERIC database.

Tomlinson, C. A. (2000). Reconcilable differences: Standard-based teaching and differences. Educational Leadership, 58(1), 6-10.

Torrance, H. and Pryor, J. (1998). Investigating Formative Assessment: Teaching, Learning and Assessment in the Classroom. Buckingham, Pha: Open University Press.

White, J. (Ed.) (1999). Impact no. 1. Educational Assessment: A Critique of Current Policy. GB: The Philosophy Education Society of GB.

Williams, W. M. and Sternberg, R. J. (1993). Seven lessons for helping children make the most of their abilities. Educational Re- 
searcher, 13(3-4), 317-331.

Wolfe, P. (2001). Brain Matters: Translating Research into Classroom Practice. Alexandria, VA: ASCD.

Wood, D. (1998, 2nd Edn.). How Children Think and Learn: The Social Contexts of Cognitive Development. Oxford: Blackwell Pub.

Yan, Zi. (2020). Self-assessment in the process of self-regulated learning and its relationship with academic achievement. Assessment \& Evaluation in Higher Education, 45(2), 224-238.

Zimmerman, B. J. (1996). Enhancing student academic and health functioning: A self-regulatory perspective. School Psychology Quarterly, 11(1), 47-66. 